\title{
PENDIDIKAN KELUARGA BERWAWASAN GENDER PADA ANAK BERKEBUTUHAN KHUSUS DI KUDUS
}

\author{
Muzdalifah M Rahman \\ Jurusan Tarbiyah STAIN Kudus \\ muzdakudus@gmail.com
}

\section{ABSTRAK}

Penelitian ini bertujuan untuk mendeskripsikan tentang peran orang tua dalam pendidikan berwawasan gender keluarga pada anak berkebutuhan khusus. Penelitian ini mneggunakan pendekatan penelitian kualitatif. Pengumpulan data dengan metode observasi dan wawancara mendalam yang diperoleh dari subyek penelitian sebanyak tiga orang. Hasil penelitian menunjukkan bahwa subyek 1 menganggap bahwa memiliki anak laki-laki berumur 6 tahun berkebutuhan khusus dengan menderita cerebral palsy. Subyek 2 menyatakan memiliki anak perempuan yang berumur 23 tahun yang berkebutuhan khusus berupa cacat kaki. Subyek 3 memiliki anak perempuan berumur 30 tahun berkebutuhan khusus yaitu hidrosefalus. Subyek 1 dan 2 menganggap bahwa pendidikan tetap diberikan kepada anak berkebutuhan khusus dengan berkeadilan gender. Subyek 3 menganggap bahwa pendidikan tidak perlu diberikan kepada anak berkebutuhan khusus .Perbedaan mendidik dalam keluarga ini dipengaruhi oleh faktor tingkat pendidikan, kenyakinan, harapan masa depan, faktor ekonomi dalam keluarga. 
Kata Kunci : Anak Berkbutuhan Khusus, Gender, Pendidikan Keluarga

\section{ABSTRACT}

This study aims described the role of parents in the education gender responsive family on children with special needs. This study used qualitative research approach. The collection of data by the method of observation and in-depth interviews were obtained from three research subjects. The results showed that subjects one considers that having a boy was 6 years old with special needs suffering from cerebral palsy. Subjects 2 states had a daughter who was 23 years old with special needs in the form of deformed feet. 3 subjects had a 30 year-old danghter with special needs, namely hydrocephalus. Subjects 1 and 2 assumed that education still be given to children with special needs by gender. Subjects 3 considers that education should not be given to children with special needs in the family. The difference of education is influenced by the level of education, the assurance, the future expectations, economic factors in the family.

Keywords : Children with Special Needs, Gender, Family Education

\section{A. Pendahuluan}

Penyandang disabilitas atau sebagai orang cacat yang dianggap sebagai warga masyarakat yang tidak produktif, tidak mampu mnejalankan tugas dan tanggung jawabnya sehingga hakhaknya pun diabaikan. Indonesia merupakan Negara yang memiliki berbagai resiko kecacatan. Konflik berkepanjangan di Aceh dan Papua, konflik horizontal di Maluku dan di berbagai daerah seluruh Indonesia karena perbutan lahan, pekerjaan, atau pelanggaran adat tertentu, berbagai bencana alam di berbagai daerah sepanjang tahun, masih adanya insiden penyakit polio dan lepra yang memiliki prevalensi 0,76/10.000 penduduk pada tahun 2008, kekuarangan 
vitamin A, tingginya strocke dengan prevalensi 8,3/1000 pendududk , serta buruknya keselamatan pasien dalam praktek kedokteran (Depkes RI, 2008 dalam Aloewie Tjepi F, 2000: 1-2).

Menurut data World Health Organization (WHO) sampai tahun 2002 3\% - 5\% dari 10 juta penduduk Indonesia atau sekitar 10,5 juta orang adalah penyandang disabilitas. Disabilitas, dari segi kuantitas, merupakan kelompok minoritas dalam masyarakat, tetapi mereka masih memiliki potensi yang dapat diandalkan sesuai dengan kecacatannya melalui proses-proses khusus, dan merekapun merupakan sumber daya manusia yang menjadi bagian dari aset nasional. Hal ini ditunjang dengan diterimanya Deklarasi Hak-hak Penyandang Cacat oleh Perserikatan Bangsa-Bangsa (PBB) pada tanggal 9 Desember 1975 yang antara lain menyebutkan bahwa difabel mempunyai hak yang sama dalam masyarakat, termasuk hak untuk berperan serta dan ikut memberi sumbangan pada semua segi kehidupan ekonomi, sosial dan politik. Menurut Undang-Undang Republik Indonesia No. 4 Tahun 1997 tentang Penyandang Cacat, difabel merupakan bagian dari masyarakat Indonesia yang mempunyai kedudukan, hak, kewajiban dan peran yang sama dengan masyarakat Indonesia lainnya di segala aspek kehidupan dan penghidupan. Akan tetapi Undang-Undang Republik Indonesia No. 4. Tahun 1997 tentang Penyandang disabilitas ini belum terimplementasikan dengan baik di masyarakat ( Demartoto, 2005: 2).

Anak-anak tidak luput dari permasalahan disabilitas .Kehidupan manusia tidak pernah statis, sejak lahir sampai meninggal manusia selalu mengalami perubahan. Perubahan yang dialami merupakan integrasi dari berbagai perubahan struktur dan fungsi sehingga mepengaruhi perkembangan fisik, kognisi, emosi, sosial dan kepribadian. Namun demikian tidak semua anak mampu melewati perkembangannya dengan baik. Banyak anak yang memiliki keterbatan fungsional seperti tunanetra, tunarungu, autis. Selain itu banyak anak yang memiliki kekhususan lain dengan gangguan pemusatan perhatian (ADHD), anak kesulitan belajar (disleksia, 
disgrafia, diskalkulia) dan anak lambat belajar (Slow Learner).

Disabilitas pada anak-anak atau sering disebut sebagai Anak Berkebutuhan Khusus (ABK) di atas sering mendapatkan stigma masyarakat dengan label negatif seperti si bisu, si pincang, si buta yang memang sering kita dengar di masyarakat. Keadaan seperti inilah yang menjadikan orang tua menyembunyikan anaknya sehingga mereka tidak berkembang secara optimal (Agustyawati, 2009; 1).

Keadaan tersebut bertolak belakang seperti yang dialami oleh Bahrul Fuad yang sejak kecil tidak membuatnya menyerah pada takdir. Hidup memang tidak mudah bagi penyandang disabilitas. Dengan rasa percaya diri yang tinggi Fuad menjadi Kooordinator Center on Difable Community Development and Empower sejak semester 3 di Universitas Darul Ulum Jombang dan dia juga menyelesaikan pendidikan S2 di bidamg Humanitarian Assistance di Universitas Gronigen Belanda. Keadaan difabel yang memberikan pelajaran untuk Fuad supaya tulus menerima kondisi tubuh dan selalu memanjatkan syukur atas nikmat Allah dalam menjalani hidup supaya mampu berbuat baik diri, keluarga dan masyarakat luas (Geniofam, 2010: 103-104)

Cerita di atas merupakan salah satu contoh dari sekian anak berkebutuhan khusus yang berhasil meraih sukses. Anak berkebutuhan khusus bila memiliki motivasidiri dengan kekuatan diri dan mendapatkan motivasi dari luar diri berupa dukungan social berupa pengasuhan dan pendidikan keluarga berwawasan gender akan mampu mengantarkan individu untuk mampu mengembangkan potensi-potensi yang dimilikinya yang pada akhirnya dapat meraih cita-citanya dalam hidup yang berujung pada kebahagiaan.

Kasus di atas sama seperti penelitian yang pernah dilakukan oleh Cynthia Rusdian pada tahun 2012 ditemukan bahwa ada hubungan antara psychological well-being dan keterlibatana orang tua dalam pendidikan anak disabilitas intelektual kanak-kanak (411 tahun) sebesar nilai $r=0,442$ (Rusdian Cynthia, 2012: 53) 
Dari pemaparan di atas perlu penulis tegaskan penelitian ini memiliki beberapa tujuan. Menurut Moleong ada dua maksud tertentu yang diinginkan peneliti dalam menetapkan focus. Pertama, penetapan focus untuk membatasi studi. Kedua, penetapan fokus itu berfungsi untuk memenuhi criteria inlusi-eksklusi (memasukkan dan mengeluarkan) suatu informasi berfungsi yang berfungsi yang baru diperoleh dari lapangan (Moleong, 1991: 10).

Untuk mencapau tujuan tersebut, maka peneliti melakukan focusing dalam dua hal; (1) Pengasuhan dan pendidikan keluarga berwawasan gender yang diberikan orang tua kepada anak berkebutuhan khusus; (2) Hasil dari proses pengasuhan dan pendidikan keluarga berwawasan gender yang diberikan kepada anak berkebutuhan khusus.

Sebagai argumentasi pentingnya penelitian ini, peneliti memaparkan dua manfat penting: (1) Manfaat teoritis, dapat bermanfaat sebagai sumber informasi bagi penelitian mengenai pendidikan keluarga berwawasan gender pada anak berkebutuhan khusus; (2) Manfaat praktis, bermanfaat khususnya bagi orang tua anak berkebutuhan khusus supaya memberikan pendidikan yang maksimal sejak usia dini serta memberikan penhgetahuan kepada pembaca pada umumnya dan pemerhati anak berkebutuhan khusus dalam memberi dukuangan dan masukan bagi pendidikan anak berkebutuhan khusus.

Untuk memperjelas proses riset dan menghindari salah paham, maka beberapa batasan istilah dan makna operasional perlu, peneliti jelaskan sebagai berikuT:

\section{Gender}

Kata gender berasal dari bahasa Inggris berarti jenis kelamin. Dalam Webster's New World Dictionary, gender diartikan sebagai perbedaan yang tampak antara laki-laki dan perempuan dilihat dari segi nilai dan tingkah laku. Dalam Women's Studies Encyclopediadijelaskan bahwa gender adalah suatu konsep kultural 
yang berupaya membuat pembedaan (distinction) dalam hal peran, perilaku,mentalitas, dan karakteristik emosional antara laki-laki dan perempuan yang berkembang dalam masyarakat. Sedangkan Hilary M. Lips mengartikan gender sebagai harapan-harapan budaya terhadap lakilaki dan perempuan (cultural expectations for women and men). Pendapat ini sejalan dengan pendapat kaum feminis, seperti Lindsey yang menganggap semua ketetapan masyarakat perihal penentuan seseorang sebagai laki-laki atau erempuan adalah termasuk bidang kajian gender (What a given society defines as masculine or feminin is a component of gender (Suhra, 2013: 376).

Gender adalah perbedaan peran fungsi, persifatan, kedudukan, tanggung jawab dan hak perilaku baik perempuan maupun lakilaki yan dibentuk, dibuat, dan disosialisasikan oleh norma, adat kebiasaan dan kepercayaan masyarakat setempat. Dalam kaitan ini, konsep relasi gender berhubungan dengan peran dan tugas yang pantas atau tidak pantas, baik laki-laki maupun perempuan (KPP, 2004). Adapun relasi gender adalah hubungan antara laki-laki dan perempuan berkaitan dengan peran yang dijalankan masingmasing pada tipe dan sstruktur keluarga ( keluarga miskin atau kaya, keluarga desa/kota, keluarga lengkap/tunggal, keluarga punya anak/ tidak punya anak, keluarga pada berbagai tahapan lif cycle. Relasi ini diperluas secara bertahap berdasarkan luasan ekologi, mulai dari mikro, meso dan makro (keluarga besar, masyarakat regional, masyarakat nasional, bangsa dan negara dan masyarakat internasional (Puspitawati, 2007 dalam Puspitawati, 2010: 2).

Menurut Mansour Fakih perbedaan gender akan melahirkan manifestasiketidakadilanantaralain:terjadimarginalisasi(pemiskinan ekonomi) terhadap kaum perempuan, terjadinya subordinasi pada salah satu jenis kelamin, pelabelan negative (stereotype), kekerasan (violence), menanggung beban kerja domestic lebih banyak dan lebih lama (doble burden), pada umumnya yang menjadi korban adalah perempuan dengan adanya tradisi dan keyakinan masyarakat bahwa perempuanlah yang bertugas dan memelihara kerapian rumah, serta 
tanggung jawab atas terlaksananya keseluruhan pekerjaan domestik (Fakih, 1996: 72-75).

Ketidakadilan gender dan diskriminasi gender merupakan system dan struktur dimana baik laki-laki maupun perempuan menjadi kornban dari system tersebut (KMNPP, 2000). Berbagai perbedaan peran dan kedudukan antara laki-laki dan perempuan baik secara langsung berupa perlakuan atau sikap maupun berupa dampak suatu peraturan perundang-undangan maupun kebijakan telah melahirkan berbagai ketidakadilan yang telah berakar dalam sejarah, adat, norma maupun struktur masyarakat (KMNPP RI, 2001 dalam Widayani dan Hartati, 2014: 153).

\section{Anak Berkebutuhan Khusus}

Penyandang disabilita satau disebut anak berkebutuhan khusus adalah anak yang hidup dengan karakteristik khusus dan memiliki perbedaaan dengan anak pada umumnya. Karena karakteristik yang berbeda inilah ABK memerlukan pelayanan khusus agar di mendapatkan hak-haknya sebagai manusia yang hidup di muka bumi. Ia selalu menunjukkan ketidakmampuan mental, emosi, dan juga fisik. Termasuk dalam kategori ABK adalah tunanetra, tunarungu, tunagrahita, tunadaksa, tunalaras dan beberapa anak yang memiliki gangguan perilaku (Nur Kholis Reefani, 2013: 15).

Dalam UURI Nomor 20/2003 tentang Sistem Pendidikan Nasional Bab IV pasal 5 ayat (2), (3), dan (4) dinyatakan bahwa anak berkebutuhan khusus adalah :

- Anak yang memiliki kelainan fisik, emosional, mental, intelektual dan/ atau sosial sehingga berhak memperoleh pendidikan khusus.

- Anak di daerah terpencil atau terbelakang serta masyarakat adat yang terpencil sehingga berhak mendapatka pendidikan layanan khusus.

- Anak yang memiliki kecerdasan dan bakat istimewa sehingga berhak memperoleh pendidikan khusus. 
Dari UURI tersebut, maka dapat dijabarkan bahwa anak yang berkebutuhan khusus adalah :

- Anak yang memiliki kelainan fisik, antara lain tunanetra, tunarungu, dan tunadaksa.

- Anak dengan kelainan emosional dan/atau mental, anak dengan gangguan pemusatan perhatian , autism

- Anak dengan kelainan intelektual, yaitu tunagrahita

- Anak dengan kelainan sosial, yaitu tunalaras

- Anak dengan potensi cerdas istimewa dan bakat istimewa

- Anak di daerah terpencil seperti anak rimba, suku Badui dan lain-lain (Agustyawati dan Solicha, 2009: 4)

Adapun karakteristik anak berkebutuahan khusus akan penulis jelaskan di bawah ini sebagai berikut :

a. Tunanetra

Tunanetra adalah orang yang memiliki ketajaman penglhatan 20/200 atau kurang pada mata yang baik, walaupun dengan memakai kacamata, atau yang daerah peglhatannya sempit sedemikian kecil sehingga yang terbesar jarak sudutnya lebih dari 20 derajat (Daniel $\mathrm{P}$ hallahan dalam Mardiati Busono, 1988 dalam Geniofam 2010; 12).

Tunanetra dibedakan mejadi dua, yaitu ; Buta Total adalah orang dikatakan buta total jika tidak dapat melihat 2 jari di mukanya atau hanya melihat sinar atau cahaya lumayan yang dapat digunakan untu orientasi mobilitas. Mereka tidak dapat menggunakan huruf selain huruf Braille, kedua Low Vision adalah individu tergolong Low Vision (buta sebagian) bila melihat sesuatu mata harus didekatkan atau mata harus dijauhkan dari obyek yang dilihatnya, atau mereka memiliki gambaran kabur ketika melihat obyek. Penderita ini mneggunakan katamata atau lensa kotak.

b. Tunarungu

Adalah mereka yang memiiki hambatan dalm perkembangan indra pedengaran. Mereka tidak dapat mendengar suara atau bunyi. 
Pendidikan Keluarga Berwawasan Gender Pada Anak Berkebutuhan Khusus_

Karena tidak mendengar suara orang berbicara akibatnya anak tunarungu sekaligus memiliki hambatan bicara dan menjadi bisu. (Geniofam, 2010: 20)

Anderas Dwijosumarto (1990:1) bahwa tunarunggu dibedakan menjadi dua. Tuli (deaf), indera pendengarannya mengalami kerusakan dalam taraf berat sehingga pendengarannya tidak berfungsi lagi dan kurang dengar (low hearing), indera pendengarannya mengalami kerusakan tetapi masih berfungsi untuk mendengar dan bisa menggunakan alat bantu dengar (dalam Agustyawati dan Solicha 2009: 48).

c. Tunadaksa

Adalah penderita kelainan fisik, khususnya badan, seperti tangan, kaki atau bentuk tubuh. Petimpangan perkembangan terjadi pada ukuran, bentuk dan kondisi lainnya. Secara umum mereka memiliki kesempatan untuk aktualisasi, namun lingkungan kurang mempercayainya sehingga membuat individu ini kurang percaya diri.

Karakteristik anak ini adalah anngota tubuh kaku/lemah/ lumpuh, mengalami kesulitan dalam gerakan, terdapat cacat pada alat gerak, jari tangan kaku dan tidak dapat memegang, kesulitan pada saat berdiri, duduk, berjalan dan menunjukkan sikap tubuh yang tidak normal dan tidak dapat tenang (Geniofam, 2010: 22-23) d. Tunagrahita

Menurut American Association on mental Deficiency (AAMD) dalam B3PTKSM mendefinisikan tunagrahita sebagai kelainan yang meliputi fungsi intelektual di bawah rata-rata yaitu IQ 84 ke bawah berdasarkan tes dan muncul sebelum usia 16 tahun (Geniofam, 2010: 24)

Karakteristik anak tunagrahita menurut Brown et al (1991; Wolery\& Haring, 1994 pada Exceptional Children, fifth edition, p. 485-486, 1996) adalah lamban dalam mempelajari hal-hal yang baru, kesulitan dalam menggeneralisasikan dan mempelajarai halhal yang bau, emmpuan bicaranya sangat kurang bagi tunagrahita 
berat, kurang mampu dalam menolong diri sendiri, tingkah laku dan interaksinya tidak lazim yang mungkin disebabkan kesulitan tunagrahita dalam memberikan perhatian pada lawan main dalam sebuah permainan, dan perilakunya kurang wajar terus menerus karena kemungkinan tanpa tujuan yang jelas bagi tunagrahita berat (dalam Agustyawati dan Solicha, 2009: 152).

e. Tunalaras

Adalah anak yang mnegalami gangguan emosi dan perilaku. Secara fisik, penderita tunalaras tidak memiliki perbedaan mencolok daripada anak normal. Umumnya mereka berperilaku aneh. Ciri-ciri anak ini adalah bersikap membangkang, mudh terangsang emosinya, sering melakukan tindakan agresif dn melanggar norma sosial/susila/ hukum (Geniofam, 2010: 27-28).

f. Autis

Autis secara harfiah berasal dari bahasa Yunani yaitu Auto yang artinya sendiri. Hal ni karena dilatarbelakangi oleh kenyataan bahwa anak autis paada umumnya hidup dengan dunianya sendiri, menikmati kesendirian dan tidak merespon orang-orang di lingkungan sekitar. Adapun kriterianya adalah ; tidak memiliki bahasa, mudah tertawa dan mrah secara bersamaan, sulit menangkap pembicaraan oag lain dan seing menggunakan isyarat ketika berkomunikasi dengan orang lain (Geniofam, 2010: 29).

Dari beberapa cacatan medis diyakini bahwa gangguan autis merupakan sindrom perilaku yang dapat disebebkan oleh berbagai kondisi yang mempengaruhi sistem syaraf pusat. Walaupun begitu samapi sekarang belum diketahui secara pasti dimana letak keabnormalitasnya. Hal ini diduga karena adanya disfungsi batang otak dan mesolimbik dan penelitian terakhir ada kemungkinan keterlibatan dari serebelum (Nur Kholis Reefani, 2013: 33).

g. Down Syndrome

Penyakit ini sudah diketahui sejak tahun 1866 oleh Dr.Landon Down, tetapi baru pada awal tahun enam puluhan ditemukan 
Pendidikan Keluarga Berwawasan Gender Pada Anak Berkebutuhan Khusus_

diagnosis secara pasti dengan pemeriksaan kromosom. Dahulu penyakit ini dinamakan Mongoloid atau Mongolism karena penderitanya memiliki gejala fisik yang khas dengan wajah seperti seperti orang Mongol dan mata sipit membujur ke atas. Maka dilanjutkan penyakit ini dinamakan Down Syndrome. Penyakit ini terjadi karena kelainan genetis, tetapi bukan karena penyakit keturunan (diwariskan). Adapaun karakteristis penderita ini adalah cacat mental dan kepekaan yang tinggi pada leukemia, menapakkan wajah bodoh dan rekasi lamban, IQ rendah antara 50-70, kadang sampai 90, pigmentasi rambut dan kulit tidak sempurna dan bertubuh pendek (Geniofam, 2010: 35-36).

\section{h. Slow Learner}

Slow Learner atau anak lambat belajar adalah anak yang memiliki potensi intelektual sediit di bwah normal tetapi belum termasuk tunagrahita. Adapun klaasifikasi anak lambat belajar dapat digolongkan : rentang IQ 70-90, lambat dalam perkembangannya, misalnya umur 2 tahun baru dapat berjalan dan berbicara pada umur 2,5 tahun, lambat belajar karena faktor psikhis misalnya neurosa, lambat belajar karena faktor organis misalnya karena epilepsi, kerusakan otak, dan lambat belajar karena terlalu emosionil (Agustyawati dan Solicha, 2009; 196-197).

i. Kesulitan Belajar Khusus (Disleksia, Disgrafia dan Diskalkulia)

Kata dyslexia dari Yunani (dys yang berarti "sulit dalam" dan lex dari legein yang artinya "berbicara". Jadi secara harfiah adalah kesulitan berhugan dengan kata atau simbol-simbol tulis. Istilah ini banyak digunakan dalam dunia kedokteran dan dikaitkan dengan gangguan neurofisologis. Gangguan ini bukan disebabkan dari ketidakmampuan fisik seperti masalah penglihatan tetapi mengarah pada bagaimana otak mengolah dan memproses informasi yang dibaca oleh anak. Penderita ini tidak akan selamany menderita gangguan membaca dan menulis, sebab ketika pertumbuhan otak dan sel otak sempurna ia dapat mengatasinya. 
Gangguan masalah otak juga akan menjadikan anak megalami kesulitan belajar menulis atau disebut dysgraphia. Adalah ketidakmampuan dalam mengharmonisasikan ingatan dengan penguasaan gerak tngannya ketika sedang menulis angka atau huruf.

Selain dyslexia dan dysgraphia, ada gangguan yang berhubungan dengan sistem syaraf pusat yaitu dyscalculis. Adalah kesulitan belajar matematika. Ketidakmampuan ini dalam hal mengartikan angka ke dalam simbol, serta sulit memahami arti kata dalam berhitung, yaitu adanya gangguan pada kemampuan kalkulasi secara matematis ( Agustyawati dan Solicha, 2009: 208-212) .

j. Gangguan Pemusatan Perhatian dan Hiperaktif

Istilah Attention Deficit Hiperactive Disorder (ADHD) pertama kali diperkenalkan oleh Dr. Henrich Hoffman pada tahun 1845 di kalangan medis yang belumdiakui secara esmi sebagai suatu penyakit atau gangguan.

Menurut Taylor (1988) gangguan pemusatan perhatian dan heraktivitas adalah suatu pola perilaku pada seseorang yang menujukkan sikap tidak mau diam, tidak mau menaruh perhatian, impulsive (semauanya sendiri) sehingga sering membuat kekacauan yang terkadang menganggu teman-temannya (Agustyawati dan Solicha, 2009: 256-257).

k. Anak berbakat istimewa

Konsep keberbakatan menurut Renzulli bahwa memiliki tiga ciri pokok yaitu;

- Memiliki kemampuan di atas rata-rata (Above Average ability), artinya hanya kecerdasan menentukan keberbakatan dan produktivitas kreativitas seseorang

- Kreativitas di atas ata-rata (Creativity), artinya memiliki kemampuan untuk menciptakan sesuatu yang baru yang diterapkan pada pemecahan masalah.

- Pengikatan diri pada tugas (Task Commitment), artinya adanya motivasi internal mendorong seseorang tekun dan ulet dalam 
mengerjakan tugas meskipun mengalami banyak rintangan dan hambatan (Agustyawati dan Solicha, 2009: 280-281).

\section{Pendidikan Keluarga Berwawasan Gender pada Anak Berkebutuhan Khusus}

Kelahiran anak berkebutuhan khusus dapat membawa perubahan-perubahan yang sulit dalam dinamika keluarga (Hallan dan Kauffman, 2006). Oleh karena itu orang tua dan keluarga membutuhkan penyesuaian diri dalam berbagai hal. Keogh, Garnier, Bernheimer dan Gallimore (Hallan dan Kauffman, 2006) (Hallan dan Kauffman, 2006) mengungkapkan bahw kehadiran anak itu dapat merubah rutinitas keluarga . Misalnya keluarga pindah rumah agar dekat dengan tempat berobat anak. Tak hanya itu , penelitian yang dilakukan oleh Kazak dan Marvin (1984) serta beberapa peneliti lainnya (Quine dan Paul, 1985; Roach dkk, 1999; Valentine dkk, 1998 dalam Heiman, 2002) membuktikan bahwa orang tua dari anak berkebutuhan khusus mengalami stress yang tinggi daripada anak normal. Stress itu disebabkan oleh adanya tuntutan lebih pada orang tua baik dari segi waktu, energy, keuangan, emosi dan ketidakyakinan akan kemampuan mereka untuk menangani kebutuhan anak mereka (Olsen et aal, 1999 dalam McConkey, Tresdale-Kennedy, Chang, Jarrah dan Shukri, 2008 dalam Rusdian Cynthia, 2012: 1-2).

Bagaimanapun juga anak berkebutuhan khusus harus tetap mendapat pengasuhan dan pendidikan yang layak seperti anak normal lainnya dengan menerapakn pendidikan berwawasan gender. Sebab anak laki-laki dan perempuan tetap memilki kesempatan berkembang untuk meraih masa depannya.

Menurut direktorat Pembinaan pendidikan Masyarakat, Pendidikan Keluarga Berwawasan gender (PKBG) adalah upaya penyadaran pemahaman hak dan kewajiban peran laki-laki dan perempuan untuk mewujudkan keadilan dan kesetaraan gender 
dalam keluarga. Sedangkan tujuannya untuk meningkatkan pengetahuan, pemahaman, wawasan, kesadaran dan kecakapan hidup dalam berbagai hal, antara lain:

1. Perilaku adil dan setara gender terhadap anak laki-laki dan perempuan dalam keluarga

2. Saling menghormati perbedaan dan keragaman dan mneyelesaikan berbagai persoalan rumah tangga melalui dialog.

3. Kesadaran terhadap hak-hak dasar anak (perempuan dan lakilaki) khususnya di bidang pendidikan.

4. Melindungi kesehatan ibu dan anak, mencegah kematian ibu melahirkan dan bayi, mencegah penelantaran dan kekerasan terhadap anak dan memberikan perlindungan terhadap anak (marginal, terlantar, dan bermasalah denga hukum).

5. Mencari alternative pemecahan masalah pelanggaran HAM.

6. Penguatan kesejahteraan keluarga melalui pengelolaan ekonomi keluarga (Direktur Pendidikan Usia Dini, Non Formal, dan Informal, 2014: 3).

Penerapan pendidikan keluarga berwawasan gender dapat dilakukan dengan memenuhi kebutuhan-kebutuhan anak dalam hidup pada umumnya, mulai dari kebutuhan-kebutuhan pokok (primair) sampai kebutuhan jiwa dan sosial yang perlu dalam hidup. Adapun kebutuhan-kebutuhan itu dapat dijelaskan sebagai berikut :

a. Kebutuhan primer

Orang tua harus memperhatikan tentang makan minum anak dengan gizi yang cukup dan pakaian yang pantas untuk semua anak baik laki-laki maupun tanpa membeda-bedakan antara anak normal dengan anak berkebutuhan khusus dalam keluarga.

b. Kebutuhan kasih sayang

Kehadiran anak di dalam keluarga jika di terima dengan baik dengan pemberian kasih sayang yang cukup yang membuat anak tumbuh menjadi manusia yang percaya diri. Memberikan kasih 
sayang yang proporsional kepada semua anak tanpa pernah membeda-bedakan tanpa membeda-bedakan antara laki-laki dan perempuan, antara anak yang normal dengan anak berkebutuhan khusus adalah cara yang bijak.

c. Kebutuhan akan rasa aman

Seorang anak laki-laki atau perempuan, normal atau berkebutuhan khusus akan merasa diterima oeh orang tuanya , bila ia merasa bahwa kepentingannya diperhatikan, merasa hubungan yang erat antara ia dengan keluarganya. Ketenangan suasana keluarga merupakan syarat supaya anak menjadi aman. Jika orang tua mendapati anaknya tidak normal maka orang tua seharusnya tetap menerima anak dengan segala kekurangan dan kelebihannya. Orang tua harus percaya dan bersyukur bahwa amanah yang diberikan Allah tetap ada hikmah dan manfaatnya jika orang tua mau mencari sisi kebaikan yang dimiliki oleh anak berkebutuhan khusus tersebut. Motivasi kuat yang diberikan orang tua kepada anak akan memberi rasa aman pada anak dan membuat anak bangkit menemukan kelebihan yang dimilikinya.

d. Kebutuhan akan harga diri

Setiap anak laki-laki atau perempuan, normal atau berkebutuhan khusus ingin bahwa dia mempunyai tempat dalam keluarga, keinginannya diperhatikan, ingin supaya orang tuanya mau mendengarkan dan mengacuhkannya apa yang dikatakannya.

Menghargai anak tidak sama seperti menghargai orang dewasa. Jika anak memanggil orang tua yang asyik melakukan aktivitas dan anak memanggil keras sampai menangis dan orang tua tidak menghiraukannya maka anak akan sakit hati karena kebutuhannya tidak dihargai. Jadi bila anak berbicara kepada orang tua berusahalah melihat kepadanya. Jika tidak maka anak merasa tidak dihargai.

Olok-olok dalam bentuk apapun menyebabkan anak tidak dihargai , apalagi kepada anak berkebutuhan khusus. Hukuman- 
huuman, perintah-perintah, larangan-larangan dan janjijanji akan mneghukum dengan alasan yang tidak wajar akan mneyebabkan anak merasa tidak dihargai.

Jangan pernah ada olok-olok terhadap anak berkebutuhan khusus dalam keluarga, sebab olok-olok akan membuat anak tersebut patah semangat. Jika patah semangat maka aan tidak mungkin akan tergali kelebihan yang dimilikinya.

e. Kebutuhan akan kebebasan

Kebebasan yang dimaksud bukanlah kebebasan tidak mengenal batas, tetapi kebebasan dalam batas-batas kewajaran. Dalam hal permainan anak-anak yang berfungsi mengembangkan kemampuan motorik misalnya mendorong meja, lompat tali, naik turun tangga, lompat, jungkir balik dan sebagainya diberi kebebasan asal permainan tersbut tidak membahayakan jiwa anak. Begitu juga kebebasan bergaul dengan dengan teman sebayanya dengan tetap memberikan pengawasan terkiat aktivitas anak dengan teman sebayanya.

Orang tua sebaiknya memberikan kebebasan kepada anakanak untuk bisa menggali potensinya. Jika anak tertarik untuk mengembangkan potensinya tersebut, maka tentunya orang tua memberikan fasilitas pendidikan yang mendukung pada pengembangan bakat atau potensi anak baik anak laki-laki atau perempuan, normal atau berkebutuhan khusus.

f. Kebutuhan akan sukses

Rasa sukses yang dicapai oleh anak baik laki-laki atau perempuan, normal atau berkebutuhan khusus di waktu kecil akan mempengaruhi hidup di kemudian hari, anak yang biasa mendapatkan apa yang diinginkan secara wajar dan tidak berlebihan akan mempunyai pandangan hidup yang optimis di kala ia besar nanti dan hidupnya penuh dengan seanagat dan kegembiraan. Sebaliknya, anak yang sering kali gagal dalam memenuhi kebutuhannya ia akan mempunyai pandangan hidup 
yang pesimis, ragu dan tidak berani menghadapi kesukarankesukaran, walaupun kesukaran-kesukaran itu kecil dan ringan (Daradjat, 2001: 59-92).

Sukses atau gagalnya usaha seseorang tidak lepas dari dukungan orang tua. Anak akan menjadi sukses jika mendapatkan kasih sayang yang cukup, mendapatkan rasa aman, kebutuhan harga dirinya terpenuhi dan memiliki kebebasan untuk mengembangkan potensi atau bakatnya.

Untuk menemukan data tentang pendidikan keluarga berwawasan gender pada Anak Berkebutuhan Khusus (ABK) di masyarakat dengan unsur-unsur pokok yang harus ditemukan sesuai dengan butir rumusan masalah, tujuan dan manfaat penelitian, maka digunakan metode kualitatif. Alasan utamanya adalah karena masalah masih bersifat sementara, tentatif dan akan berkembang atau berganti setelah peneliti berada di lapangan. (Sugiyono, 2007: 283).

Karena penelitian kualitatif, maka instrument utama penelitian ini adalah peneliti sendiri, namun selanjutnya setelah permasalahan menjadi jelas dan pasti, maka akan dikembangkan instrument penelitian sederhana yang diharapkan dapat melengkapi data melalui observasi dan wawancara.

Dalam penggalian data, penelitian dilakukan terhadap anggota masyarakat di Kabupaten Kudus dengan subyek penelitian sebanyak tiga orang tua dalam mendidik anak-anaknya. Data ini digali dari sumber data primer dan data sekunder. Sumber primer adalah sumber data yang langsung memberikan data kepada pengumpul data. Sumber data sekunder merupakan sumber yang tidak langsung memberikan data kepada pengumpul data, misalnya lewat orang lain atau dokumen (Sugiyono, 2007; 308-309).

Adapun sumber data primer ini melalui wawancara terhadap pendidikan damai dalam keluarga dengan latar belakang budaya jawa.Sumber data sekunder diperoleh dari dokumen-dokumen resmi atau kepustakaan yang tersedia berhubungan dengan fenomena yang 
diteliti dan dari laporan-laporan media massa umum, jurnal, buku, makalah, dan laporan penelitian yang mengupas tentang pendidikan keluarga berwawasan gender.

Dalam penelitian ini, pengumpulan data tidak dipandu oleh teori, tetapi dipandu oleh fakta-fakta yang di temukan pada saat penelitian di lapangan. Tekhnik pengumpulan data merupakan langkah yang paling strategis dalam penelitian, kerena tujuan utama dari penelitian adalah mendapatkan data. Tanpa mengetahui tekhnik pengumpulan data, maka peneliti tidak akan mendapatkan data yang memenuhi standar yang ditetapkan.

Adapun tekhnik pengumpulan data yang peneliti gunakan dalam penelitian ini adalah kombinasi antara metode wawancara semi terstruktur, dokumentasi, dokumentasi. Pemenfaatan metode penggalian data akan disesuikan dengan sifat data yang saling melnegkapi dan menguatkan.

Data yang terkumpul akan dianalisa dengan tahapan: (1) Analisis yang dilakukan peneliti sebelum di lapangan. Analisis ini dilakukan terhadap data hasil studi pendahuluan atau data sekunder yang akandigunakan peneliti untuk menentukan fokus penelitian. Tetapi fokus penelitian ini masih bersifat sementara, dan akan dikembangkan oleh peneliti dan selama di lapangan. (2) Analisis yang dilakukan peneliti selama di lapangan. Analisis data dalam penelitian kualitatif dilakukan pada saat pengumpulan data berlangsung dan setelah selesai pengumpulan data dalam periode tertentu. Pada saat wawancara, peneliti melakukan analisis terhadap jawaban yang diwawancarai. Bila jawaban dari yang diwawancarai peneliti setelah dianalisis dirasakan belum memuaskan, maka peneliti akan melanjutkan pertanyaan lagi, sampai data-data yang dianggap kredibel. Miles and Huberman (1984) mengemukakan bahwa analisis data dilakukan secara interaktif dan berlangsung terus menerus sampai tuntas, sehingga datanya sudah jenuh. Aktivitas dalam analisis data, yaitu data reduction, data display, dan conclution (Sugiyono, 2007: 336-337). 


\section{B. Pembahasan}

Pengasuhan dan pendidikan keluarga berwawasan gender yang diberikan orang tua kepada anak berkebutuhan khusus

Tiap keluarga memiliki konsep yang berbeda dalam memberikan pengasuhan dan pendidikan kepada anak-anaknya. Subyek 1 adalah orang tua yang memiliki anak laki-laki yang menderita Cerebral Palsi dengan usia 6 tahun. Pekerjaan mereka adalah guru. Orang tua tersebut tentunya memiliki pemahaman tentang pendidikan berwawasan gender sehingga didalam pengasuhan dan pendidikan anak tidak pernah membedakan anak laki-laki dan perempuan, anak normal atau anak berkebutuhan khusus.

Subyek 2 adalah orang tua dengan anak perempuan yang mengalami cacat tubuh pada kaki kirinya (Tunadaksa). Anak dari orang tua ini adalah anak pertama yang berumur 23 tahun dengan adiknya dua orang yang berjenis kelamin laki-laki. Orang tua ini berusaha memberikan pengasuhan dan pendidikan yang layak untuk anak itu secara berkeadilan gender.

Subyek 1 dan 2 memiliki wawasan gender dalam pendidikan keluarganya. Peran gender dengan menggunakan konsep androgini. Konsep androgini merupakan konsep pendidikan bebas gender yang mengasumsikan bahwa laki-laki dan perempuan mempunyai potensi sama untu menjadi maskulin dan feminine, sehingga memang perlu dilakukan secara sama (Megawangi, 1999 dalam Widayani dan Hartati, 2014: 153).

Subyek 3 adalah orang tua yang memiliki anak yang mengalami hidrosefalus. Orang tua ini tidak bisa memberikan pengasuhan dan pendidikan berwawasan gender. Anak ini dibiarkan tanpa pendidikan. Alasan atas tindakan yang diambil oleh orang tua ini adalah karena anak perempuan, dan bagi keluarga merupakan aib besar.

Tidak adanya kesempatan bagi anak pada subyek 3 ini karena tidak adanya pemahaman gender dalam mengasuh maupun mendidik 
anak. Konsep dalam keluarga adalah tidak ada kesetaraan gender dimana seorang ibu sebagai konco wingking tidak bisa berbuat lebih banyak dalam memberikan pendidikan kepada anak. Ditambah lagi subyek 3 ini secara ekonomi kurang mampu dan berpendidikan rendah.

Ketidakadilan gender tersebutterjadi karena terjadi marginalisasi (pemiskinan ekonomi) terhadap kaum perempuan, terjadinya subordinasi pada salah satu jenis kelamin, pelabelan negative (stereotype), kekerasan (violence), menanggung beban kerja domestic lebih banyak dan lebih lama (doble burden), pada umumnya yang menjadi korban adalah perempuan dengan adanya tradisi dan keyakinan masyarakat bahwa perempuanlah yang bertugas dan memelihara kerapian rumah, serta tanggung jawab atas terlaksananya keseluruhan pekerjaan domestik (Fakih, 1996: 72-75).

Hasil dari proses pengasuhan dan pendidikan keluarga berwawasan gender yang diberikan kepada anak berkebutuhan khusus

Adapun keberhasilan dari pola pendidikan berwawasan gender ditemukan pada subyek 1 bahwa dengan penerimaan yang dilakukan oleh orang tua kepada anaknya tersebut memberikan dampak positif terhadap perkembangan kognitif anak itu. Karena anak tersebut sering didengarkan musik, maka anak tersebut memiliki kepekaaan terhadap musik.

Subyek 2 melaporkan anaknya mengalami tingkat rasa percaya diri yang kuat. Anak tersebut mampu menyelesaikan sekolahnya sampai tingkat SMA, lalu bekerja dan sekarang menikah.

Keterlibatan subyek 1 dan 2 sebagai orang tua dalam pendidikan diasosiasikan dengan performa akademik dan kompetensi sosial anak yang lebih positif (Kohl, lenguua dan McMahon, 2000) dan penelitian membuktikan bahwa semakin besar keterlibatan orang tua dalam program kanak-kanak bagi anaknya, maka semakin besar pula perkembangan dalam hal area kognitif, bahasa dan sosio 
emosional (castro, Bryant, Peisner-Feinberg dan Skinner, 2004 dalam Rusdian, 2012: 5).

Subyek 3 melaporkan anaknya tidak bisa berbuat apa-apa. Penyebabnya adalah orang tua mulanya malu memiliki anak tersebut dan tidak member kesempatan anak sekolah, padahal sebenarnya anaknya cerdas. Rasa malu ini berakibat pada semakin capek dan tersiksanya orang tua dalam melayani kebutuhan sehari-hari anaknya itu. Anak tersebut akhirnya tumbuh menjadi orang yang selalu tergantung pada orang lain.

Tidak berkembangnya potensi yang dimiliki oleh anak berkebutuhan khusus ini disebabkan karena kurangnya kepedulian orang tua dalam memberikan hak-haknya atau kebutuhan anak tersebut. Menurut Zakiyah Daradjat bahwa anak yang biasa mendapatkan apa yang diinginkan secara wajar dan tidak berlebihan akan mempunyai pandangan hidup yang optimis di kala ia besar nanti dan hidupnya penuh dengan seanagat dan kegembiraan. Sebaliknya, anak yang sering kali gagal dalam memenuhi kebutuhannya ia akan mempunyai pandangan hidup yang pesimis, ragu dan tidak berani menghadapi kesukaran-kesukaran, walaupun kesukaran-kesukaran itu kecil dan ringan (Daradjat, 2001: 92).

\section{Simpulan}

Segala ciptaan Allah baik ataupun buruk maka pasti akan ada hikmahnya. Manusia diciptakan Allah dengan semua kelebihan dan kekurangannya, adalah wajib untuk disyukuri. Anak adalah anugerah terindah yang dimiliki oleh keluarga. Orang tua tua bertugas mengemban amanah yang diberikan Allah kepadanya. Orang tua wajib memberikan pengasuhan dan pendidikan berwawasan gender untuk tumbuh kembang kepada setiap anaknya, baik laki-laki atau perempuan, anak normal maupun anak berkebutuhan khusus. Supaya anak berkebutuhan khusus baik laki-laki maupun memiliki masa depan yang cerah seperti anak normal lainnya maka orang 
tua berkewajiban memenuhi kebutuhan-kebutuhan anak tersebut seperti kebutuhan primer, kebutuhan kasih sayang, kebutuhan rasa aman, kebutuhan harga diri, kebutuhan akan kebebasan dan kebutuhan akan sukses dan orag tua juga memberikan bekal dengan penanaman keimanan atau ketauhidan supaya anak berkebutuhan khusus tersebut mampu menyongsong masa depan dengan optimis. 


\section{DAFTAR PUSTAKA}

Idi, Abdullah dan Safarina. (2015). EtikaPendidikanKeluarga, Sekolahdan Masyarakat. Rajawali Press. Jakarta

Aloewie, Tjepi F. (2000). Kesetaraan dan Kesempatan Kerja bagi Tenaga Kerja Penyandang Cacat . Makalah. Yayasan dan LBK Propinsi DKI .Jakarta

Daradjat, Zakiyah. (2001). Kesehatan Mental. Penerbit Toko Gunung Agung. Jakarta

Dermatoto, Argyo. (2005). Menyibak Sensivitas Gender dalam Keluarga Difabel. UNS Press. Surakarta

Fakih, Mansour. (1996). Analisis Gender dan Transformasi Sosial, Cet. I Pustaka Pelajar. Yogyakarta

Geniofam. (2010). Mengasub dan Mensukseskan Anak Berkebutuhan Khusus. Penerbit Gerai Ilmu. Yogyakarta

NurKholis Reefani. (2013). Panduan Mendidik Anak Berkebutuhan Khusus. Penerbit Imperium . Yogyakarta

Puspitawati, Herien. (2010). Persepsi Peran Gender terhadap Pekerjaan Domestik dan Publik pada Mahasiswa IPB. Jurnal Studi Gender dan Anak. Pusat Studi Gender STAIN Purwokerto. Purwokerto

Rusdian, Cynthia. (2012). .Hubungan antara psychological wellbeing dan keterlibatana orang tua dalam pendidikan anak disabilitas intelektual kanak-kanak (4-11 tahun).Skripsi. UI. Jakarta

Sugiyono, (2007). Metode Penelitian Pendidikan : Pendekatan Kuantitatif, Kualitatif dan R\& D, Bandung : Alfabeta

Suhra, Safira. (2013). “Kesetaraan Gender dalam Perspektif Al Qur'an dan Implikasinya terhadap Hukum Islam”, dalam Jurnal Al-Ulum, Volume 13 No. 2 Desember Hal. 373-394

Widayani, Ni Made, Hartati, Sri . (2014). Kesetaraan dan Keadilan 
Gender dalam Pandangan Perempuan Bali; Studi Fenomologis terhadap Penulis Perempuan Bali. Jurnal Psikologi Undip. Vol.13. No 2. Oktober. Hal. 149-162. Undip. Semarang 